\title{
MILDRONATE'S PROTECTIVE EFFECTS IN THE PERIPHERAL NERVOUS SYSTEM: STAVUDINE-INDUCED NEUROPATHY AND FORMALIN-INDUCED INFLAMMATION
}

\author{
Jolanta Pupure*, Juris Rumaks*, Sergejs Isajevs*, Olga Korzakova*, Jelena Puncule*, \\ Simons Svirskis*, Ivars Kalvinnšs**, and Vija Kluša* \\ ${ }^{*}$ Faculty of Medicine, University of Latvia, Šarlotes iela 1A, Rīga, LV-1001, LATVIA \\ E-mail: pupure@e-apollo.lv \\ **atvian Institute of Organic Synthesis, Aizkraukles iela 21, Rīga, LV-1006, LATVIA
}

Contributed by Vija Kluša

\begin{abstract}
Mildronate, previously known as a cardioprotective drug, recently was found to normalise mitochondrial processes by preventing the dysfunction of complex I in rat liver mitochondria. Previously we have shown also the ability of mildronate to prevent pathologies in the central nervous system by normalizing the expression of different signalling molecules in brain tissue. This allowed us to suggest that mildronate may possess a beneficial role also in peripheral nervous system pathologies. The present study was designed to assess the peripheral tissue damage caused by anti-HIV drug stavudine, as well as pain and inflammation caused by formalin. For this demonstration, we investigated the influence of mildronate: (1) on decreased myelin expression and increased neuron degeneration in rat sciatic nerve tissue caused by stavudine; and (2) on formalin-induced inflammation in mice. We found that mildronate protected the stavudine-induced degeneration of neurons in rat peripheral sciatic nerve without a significant influence on demyelination. In a formalin test, mildronate showed anti-inflammatory action comparable to that of indomethacin, a reference drug. The present results show that mildronate is capable of regulating peripheral nerve damage and peripheral inflammatory responses. We suggest that the multifunctional effects of mildronate can be attributed to its ability to regulate mitochondrial processes. The obtained data indicate protective effects of mildronate in different peripheral neurological pathologies.
\end{abstract}

Key words: mildronate, formalin-induced inflammation, stavudine toxicity, sciatic nerve.

\section{INTRODUCTION}

Our previous studies have shown that mildronate, a representative of aza-butyrobetaine class, attenuated processes of different tissue pathologies induced by anti-HIV drugs, used as toxic model compounds. Mildronate reduced azidothymidine-, stavudine- and lamivudine-induced over-expression of the nuclear factor kappaBp65 (NFkappaBp65) in mice cardiac tissue (Klusa et al., 2006; Isajevs et al., 2007), and protected isolated rat liver mitochondria against azidothymidine-induced hydrogen peroxide $\left(\mathrm{H}_{2} \mathrm{O}_{2}\right)$ formation and uncoupled respiration (Pupure et al., 2008). Recently we found that mildronate has also antineurodegenerative and anti-inflammatory action in the brain by regulation of the expression of signalling molecules in brain cortical tissue in mice (Pupure et al., 2010). These data allow us to suggest the protective action of mildronate also in the peripheral nervous system.

Hence in the present study we examined the effect of mildronate in a peripheral neurotoxicity model based on the mitochondria-toxic test drug stavudine, and formalin as an inflammatory reaction inducer. Stavudine is known as antiHIV drug of nucleoside-analogue reverse transcriptase inhibitor (NRTI) class, which can produce side effects by predominantly affecting the nervous system, mostly manifested as peripheral neuropathy (Scarsella et al., 2002; Cherry et al., 2006). This action differs from that of azidothymidine (also a NRTI drug), which has dramatic side effects demonstrated as cardiomyopathies (Benbrik et al., 1997; Perevjav et al., 2007). However, NRTI-induced pathology in both cardiac and nervous tissues shares the common mitochondriotoxicity (Badley et al., 2003; Collins et al., 2004; Petit et al., 2005, Lewis et al., 2006). The inhibition of mtDNA polymerase gamma (Poly) is one of the main mitochondriotoxic effects of NRTIs, causing depletion of mtDNA, alteration in activity of oxidative phosphorylation enzymes, reduction of mitochondrial ATP production, emergence of ROS, and loss of cytochrome c oxidase (Badley et al., 2003). Some studies in a peripheral neuropathy model have revealed that stavudine in a nerve growth 
factor-responsive PC-12 cell line may inhibit neurite outgrowth (Cui et al., 1997). However, no peripheral neuropathy studies with stavudine have been performed on animals.

The aim of the present study was to clarify whether mildronate may act as a protective agent in peripheral nerve tissue damage. Firstly, we examined the influence of mildronate on decreased myelin expression and increased degeneration of cells in rat sciatic nerve tissue caused by stavudine. The myelin sheath is a specific membrane, which is produced by Schwann cells in the peripheral nervous system, and oligodendrocytes in the central nervous system (Baumann and Pham-Dinh, 2001). The loss of myelin from axons of peripheral neurons is an important feature of a wide range of disorders, including neuropathic pain (Fujita et al., 2007; Ueda, 2008). Secondly, in formalin test we examined the development of inflammatory processes. The formalin test is an important animal model in the study of acute long-lasting pain (Capone and Aloisi, 2004), and it provides a two-phase model for tonic pain and localised inflammation (Tjolsen et al., 1992). Indomethacin, a nonsteroidal anti-inflammatory drug that effectively can reduce the animal paw licking pain behavior response in the second (inflammatory) phase of the formalin test (Tjolsen et al., 1992) was used as a reference drug.

\section{MATERIALS AND METHODS}

Chemicals. Stavudine (2'-3'-didehydro-2'-3'-dideoxythymidine, d4T, Zerit*, $40 \mathrm{mg}$ capsules) was obtained from Bristol-Myers Squibb (France). Mildronate [3-(2,2,2trimethylhydrazinium) propionate dihydrate] was synthesised at the Latvian Institute of Organic Synthesis, and manufactured by the Joint Stock Company Grindex (Riga, Latvia). Myelin basic protein rabbit polyclonal antibody (dilution 1 : 100, code A0623), peroxidase conjugated polyclonal goat anti-rabbit IgG, polyclonal rabbit anti-goat IgG, serum-free protein block, citrate buffer, $0.5 \% \mathrm{H}_{2} \mathrm{O}_{2}$ and diaminobenzidine were from Dako, Denmark. Paraformaldehyde solution $(37 \%)$ and indomethacin were from SigmaAldrich, Bachem.

Mildronate was dissolved in saline and prepared as a $2 \%$ stock solution. A water suspension of stavudine (1\% stock suspensions) was made by adding 1-2 drops of $0.6 \%$ TWIN-80, and then diluting by saline to an appropriate concentration. The dose of mildronate was $100 \mathrm{mg} / \mathrm{kg}$ shown as the most active from our previous studies (Klusa et al., 2006); the stavudine dose was taken from literature (Weber et al., 2007). Saline plus a corresponding amount of TWIN-80 served as the control solution.

Animals. Animals were obtained from the Laboratory of Experimental Animals, Rīga Stradiňš University, Rīga, Latvia: Wistar male rats each weighing $180.0 \pm 9.5 \mathrm{~g}$ at the beginning of the experiment for stavudine-induced peripheral neuropathy test; ICR male mice, each weighing $16.9 \pm 1.5 \mathrm{~g}$ at the beginning of the experiment for the formalin-induced licking paw test. The environment was maintained at $22.0 \pm$
$0.5{ }^{\circ} \mathrm{C}$ with a 12 -h light/dark cycle, animals were fed a standard laboratory diet.

Experimental design for stavudine-induced peripheral neuropathy in rats. A nine-week (five plus four) experiment was carried out in rats by drug daily administration_at a volume of $10 \mathrm{ml} / \mathrm{kg}$ intraperitoneally in both left and right sides of the following rat groups (10 animals per group):

Group I or $[\mathrm{C}(5 \mathrm{w})+\mathrm{C} / \mathrm{C}(4 \mathrm{w})]$ : saline (left), five weeks + saline (left side) and saline (right), four weeks;

Group II or $[\mathrm{S}(5 \mathrm{w})+\mathrm{S} / \mathrm{C}(4 \mathrm{w})]$ : stavudine $(50 \mathrm{mg} / \mathrm{kg}$, left), five weeks + stavudine $(50 \mathrm{mg} / \mathrm{kg}$, left) and saline (right), four weeks;

Group III or $[\mathrm{S}(5 \mathrm{w})+\mathrm{C} / \mathrm{C}(4 \mathrm{w})]$ : stavudine $(50 \mathrm{mg} / \mathrm{kg}$, left), five weeks + saline (left) and saline (right), four weeks;

Group IV or $[\mathrm{C}(5 \mathrm{w})+\mathrm{C} / \mathrm{M}(4 \mathrm{w})]$ : saline (left), five weeks + mildronate $(100 \mathrm{mg} / \mathrm{kg}$, left) and saline (right), four weeks;

Group V or $[\mathrm{S}(5 \mathrm{w})+\mathrm{S} / \mathrm{M}(4 \mathrm{w})]$ : stavudine $(50 \mathrm{mg} / \mathrm{kg}$, left), five weeks + stavudine $(50 \mathrm{mg} / \mathrm{kg}$, left $)$ and mildronate $(100$ $\mathrm{mg} / \mathrm{kg}$, right), four weeks;

Group VI or $[\mathrm{S}(5 \mathrm{w})+\mathrm{C} / \mathrm{M}(4 \mathrm{w})]$ : stavudine $(50 \mathrm{mg} / \mathrm{kg}$, left $)$, five weeks + mildronate $(100 \mathrm{mg} / \mathrm{kg}$, left) and saline (right), four weeks.

On day 64 , the rats were sacrificed by decapitation, and sciatic nerve in $1 \mathrm{~cm}$ length from its beginning at the level of segments L4-L6 was removed and fixed in 10\% neutral buffered formalin, processed and embedded in paraffin routinely.

Formalin-induced licking paw test in mice. The formalininduced licking paw test was adopted from the method described elsewhere (Bellasio et al., 2003). Male mice (10 animals per group) received pre-treatment (for two weeks prior to formalin injection) of mildronate (or saline for the control group). Mildronate was injected daily intraperitoneally at a dose of $100 \mathrm{mg} / \mathrm{kg}$; indomethacin as the reference drug was administered daily at a dose $5 \mathrm{mg} / \mathrm{kg}$ intraperitoneally. Mice were gently restrained and $30 \mu \mathrm{l}$ of formalin solution ( $1.5 \%$ in saline) was injected subcutaneously into the plantar surface of the right hind paw, using a microsyringe with a 27-gauge needle. Each mouse was then placed in an individual clear Plexiglas observation chamber $(30 \times 20 \times 30 \mathrm{~cm})$ and the total licking time of hind paw of each mouse was registered with a stopwatch and quantified in subsequent 5-min intervals for $60 \mathrm{~min}$. All assessments were carried out blind to the treatment observers. The recording (in seconds, s) of licking time (first phase) started immediately and lasted for 5 minutes. The late phase (second phase) started about 15-20 min after formalin injection and lasted up to 35 minutes.

Immunohistochemical assessments. Paraffin-embedded tissues were cut in 4-micron-thick sections. According to the immunohistochemical method described elsewhere (Di Stefano et al., 2002) rat nerve tissue sections were stained 
for visualisation of myelin positive cells. Briefly, antigen retrieval was achieved by treatment in a microwave oven for $20 \mathrm{~min}$ at $450 \mathrm{~W}$ in citrate buffer, $\mathrm{pH}=6.0$. Endogenous peroxidase activity was blocked by $0.5 \% \mathrm{H}_{2} \mathrm{O}_{2}$ for $10 \mathrm{~min}$ utes. Nonspecific primary antibody binding was blocked by serum-free protein block for 10 minutes. Rabbit polyclonal anti-myelin antibody was applied at $1: 100$ and incubated for one hour. Detection of primary polyclonal rabbit antimyelin antibody binding was performed using specific peroxidase conjugated polyclonal goat anti-rabbit IgG (at 1 : 100 for $30 \mathrm{~min}$ ) and, subsequently, by peroxidase conjugated polyclonal rabbit anti-goat IgG at 1 : 100 for 30 minutes. The immunoperoxidase colour reaction was developed by incubation $(7 \mathrm{~min}$ ) with diaminobenzidine. A negative control without primary antibody was included in each staining run. Myelin expression in rat nerve tissue was expressed in scores: 0 - expression of myelin less than $25 \%$ of all nerve fibers; 1 - expression of myelin between $25 \%$ and $50 \% ; 2$ - expression of myelin between $50 \%$ and $75 \% ; 3-$ expression of myelin more than $75 \%$ from all nerve fibers. Slides were coded and counted blind by two pathologists.

Morphological assessment. Morphometrical analysis of rat nerve tissue was performed using image analysis software Motic Image Advanced 3.2 (Motic, Xyamen, China). Paraffin-embedded rat nerve tissue was cut in 4 micron-thick sections and stained with haematoxylin and eosin and cresyl violet for morphological examination. The total number of degenerated cells (neurons and Schwann cells) was expressed as cells per $1 \mathrm{~mm}^{2}$ and counted in 20 high powered fields at magnification $\times 400$.

Animal ethics. All experimental procedures were carried out in accordance with guidelines of the Directive 86/609/EEC "European Convention for the Protection of Vertebrate Animals Used for Experimental and other Scientific Purposes" (1986) and were approved by the Animal Ethics Committee of the Food and Veterinary Service (Riga, Latvia).

Statistics. For statistical analysis, GraphPad Prism 4 software was used. Results are expressed as the mean $\pm \mathrm{SE}$ values, and significance was set at $P<0.05$ (unpaired t-test or Mann-Whitney $U$ test). The formalin test results were analysed using one-way ANOVA with Dunnet's multiple com- parison tests. Data from the second phase of formalin test were expressed as the area under curves (AUCs).

\section{RESULTS}

Influence of mildronate on stavudine-induced alterations in rat sciatic nerve tissue: total number of degenerative cells. Our results (Figs. 1A-C, 2) showed that stavudine administration for nine weeks [group $\mathrm{S}(5 \mathrm{w})+$ $\mathrm{S} / \mathrm{C}(4 \mathrm{w})]$ significantly increased the total number of degenerated cells in peripheral nerves, in comparison to the saline control group $[\mathrm{C}(5 \mathrm{w})+\mathrm{C} / \mathrm{C}(4 \mathrm{w})]: 14.0 \pm 2.3$ vs. $3.2 \pm 0.4$, cells $/ \mathrm{mm}^{2}, P<0.01$, cells $/ \mathrm{mm}^{2}$. A similar increase was observed also after five-week administration of stavudine followed by four-week saline adiministration [group $\mathrm{S}(5 \mathrm{w})$ $+\mathrm{C} / \mathrm{C}(4 \mathrm{w})]$. Histological data showed that stavudine caused also a small pericellular and perivascular edema (data not shown). Mildronate per se (Fig. 2) did not cause alterations in sciatic nerve tissue during a period of four-week administration followed by five-week saline administration [group $\mathrm{C}(5 \mathrm{w})+\mathrm{C} / \mathrm{M}(4 \mathrm{w})$ ]. Mildronate administered for four weeks together with stavudine after five-week stavudine administration [group $\mathrm{S}(5 \mathrm{w})+\mathrm{S} / \mathrm{M}$ $(4 \mathrm{w})]$ significantly reduced the stavudine-induced increase in the total number of degenerated cells in comparison to the nine-week stavudine-treated group $[(\mathrm{S}(5 \mathrm{w})+\mathrm{S} / \mathrm{C}(4 \mathrm{w})]$ data $\left(8.4 \pm 0.7\right.$ vs. $14.0 \pm 2.3$, cells $/ \mathrm{mm}^{2}, P<0.05$, Figs. $1 \mathrm{~A}-\mathrm{C}, 2)$. There was no significant reduction in the number of degenerated cells when mildronate was administered for four weeks after five-week stavudine administration [group $\mathrm{S}(5 \mathrm{w})+\mathrm{C} / \mathrm{M}(4 \mathrm{w})]$ compared to the corresponding group $[\mathrm{S}(5 \mathrm{w})+\mathrm{C} / \mathrm{C}(4 \mathrm{~W})]$, Fig. 2.

Influence of mildronate on stavudine-induced alterations in rat sciatic nerve tissue: expression of myelin. Administration of stavudine for nine weeks reduced the expression of myelin in rat nerve tissue by about of $30 \%$ (data not shown) in comparison to the saline control group $(1.9 \pm$ 0.1 vs. $2.7 \pm 0.2$ scores, $P=0.01$ ). Expression of myelin was also reduced, when stavudine was administered for five weeks, in comparison to the saline control $(2.1 \pm 0.1$ vs. 2.7 \pm 0.2 scores, $P<0.05)$. Four-week administration of mildronate followed by five-week saline administration per se did not cause significant alteration in myelin expression
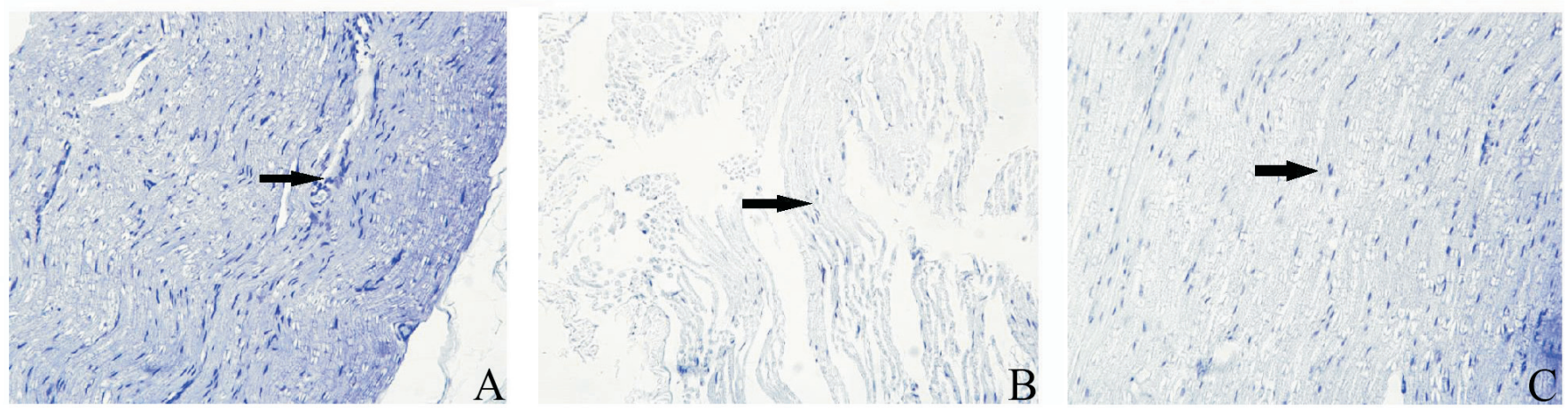

Fig. 1. Photomicrographs of rat peripheral nerve tissue stained with cresyl violet (A-C), magnification at $\times 200$. Saline control (10 ml $/ \mathrm{kg})$, stavudine $(50$ $\mathrm{mg} / \mathrm{kg}$ ), and mildronate $(100 \mathrm{mg} / \mathrm{kg}$ ) were administered intraperitoneally five + four weeks. In the control group (A) prominent cells were stained in violet colour; stavudine group (B) showed decreased staining (neurodegeneration), arrow indicates negatively stained cells; mildronate coadministration with stavudine prevented neurodegeneration $(\mathrm{C}$, arrow indicates positively stained cells). 


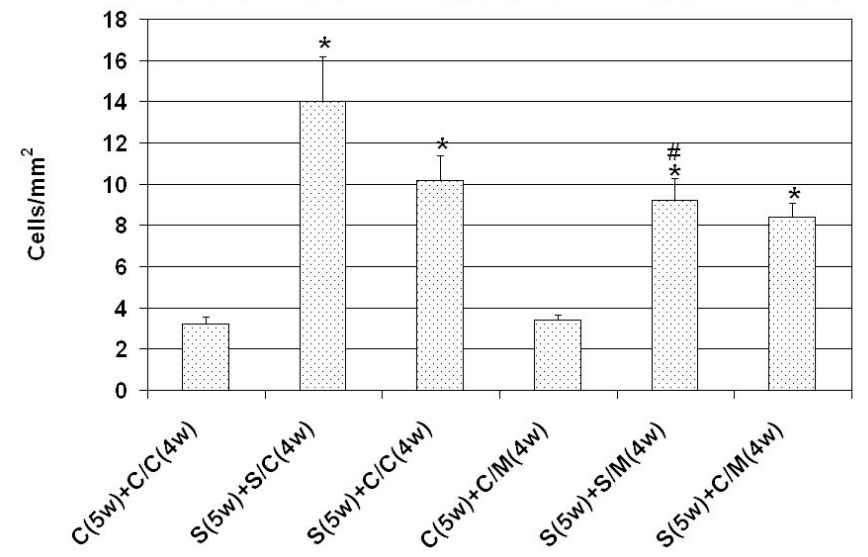

Fig. 2. Number of degenerated cells in rat sciatic nerve (cells $\left./ \mathrm{mm}^{2}\right)$. Saline control (C, $10 \mathrm{ml} / \mathrm{kg})$, stavudine $(\mathrm{S}, 50 \mathrm{mg} / \mathrm{kg})$, and mildronate $(\mathrm{M}, 100$ $\mathrm{mg} / \mathrm{kg})$ were administered intraperitoneally five $(5 \mathrm{w})+$ four $(4 \mathrm{w})$ weeks. Statistical significance expressed as: ${ }^{*} P<0.05$ vs. $\mathrm{C}+\mathrm{C} / \mathrm{C}$ group, ${ }^{\#} P<$ 0.05 vs. $\mathrm{S}+\mathrm{S} / \mathrm{C}$ group, unpaired t-test.

administration did not influence considerably the stavudine effect (data not shown).

Influence of mildronate on formalin-induced pain/inflammation. Formalin injection caused a considerable paw licking behaviour in mice in both the first phase $(0-5 \mathrm{~min}$ after injection, data not shown) and the second phase (20-35 min after injection). Two-week mildronate administration did not influence formalin-induced response in the first phase (data not shown), whereas it significantly shortened a licking time in the second phase, in comparison to control: AUC (area under curve): $212.9 \pm 33.1 \mathrm{~s}$ vs. $378.0 \pm$ 44.9 s, $P<0.01$ (Fig. 3). The effect of mildronate was comparable to that of indomethacin, a reference drug: $162.7 \pm$ 41.0 s vs. $378.0 \pm 44.9$ s, control group, $P<0.01$ (Fig. 3).

\section{DISCUSSION}

Mildronate is a well known cardioprotective drug (Dambrova et al., 2002). However, it also shows neuroprotective properties in brain tissue (Pupure et al., 2010). Recently, the effect of mildronate in normalising mitochondrial dysfunctions was also demonstrated (Pupure et al., 2008). Mildronate's efficacy in the peripheral nervous system is reported here for the first time. In the present study mildronate was shown to be capable of protecting at least in part the stavudine-induced (about four-fold) degeneration of cells in rat peripheral sciatic nerve tissue by reducing the total number of degenerated cells (by about 34\%). However, mildronate did not significantly affect stavudine-induced demyelination, probably due to the very complicated demyelination cascades of signals, which involve neurons, glia, and cells of the immune system, as well as further production of cytokines, regulation of macrophage recruitment, myelin removal, regeneration, and neuropathic pain (Abbadie et al., 2003). Our previous results showed that mildronate protected mice cardiac tissue against stavudineinduced over-expression of NF- $\mathrm{Bp} 65$, as well as cellular infiltration and necrosis (Isajevs et al., 2007). Although stavudine treatment induces a high percentage of peripheral

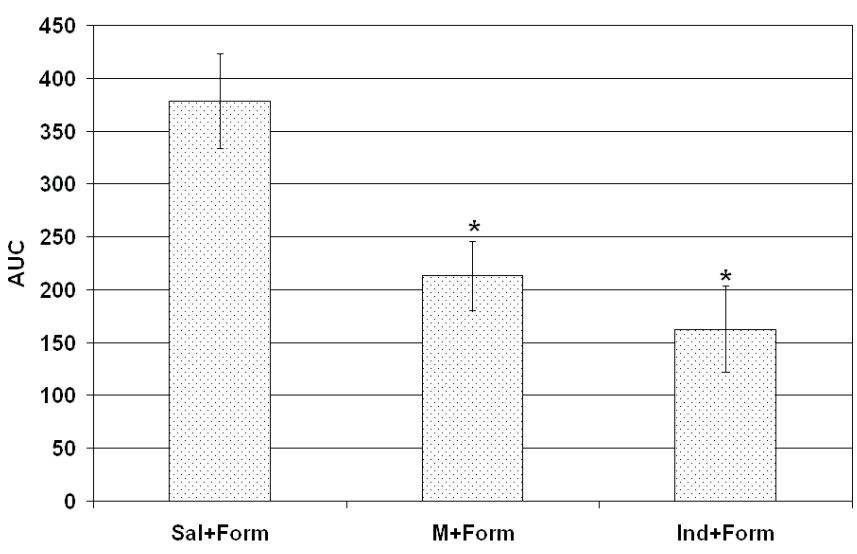

Fig. 3. Effects of saline control (Sal, $10 \mathrm{ml} / \mathrm{kg}$ ), mildronate (M, $100 \mathrm{mg} / \mathrm{kg}$ ) and indomethacin (Ind, $5 \mathrm{mg} / \mathrm{kg}$ ) on formalin (Form)-induced inflammation (second phase, 15-35 $\mathrm{min}$ ). The y axis: area under curve (AUC) for paw licking time in seconds. Statistical significance expressed as: $* P<$ 0.05 vs. Sal+Form group, One-way ANOVA with Dunnet's multiple comparison test.

neuropathies in HIV-infected AIDS patients (Scarsella et al., 2002; Cherry et al., 2006), until now there are no adequate stavudine neuropathy animal models. Our experimental schedule with a long-term (five and nine weeks) stavudine administration was in an attempt to develop a model, and the obtained results demonstrated that mildronate can reduce degenerative events in the peripheral nervous system. However, the study can be considered as preliminary. The ability of mildronate to halt degenerative processes was shown also in our recent findings, where mildronate (particularly at dose $50 \mathrm{mg} / \mathrm{kg}$ ) reduced neurodegenerative and apoptotic events in mice brain cortex by normalising the decrease in cytochrome c oxidase expression, the increase in caspase- 3 expression, as well as by reducing the expression of glial fibrillary acidic protein, and cellular infiltration (Pupure et al., 2010).

We demonstrated here the anti-inflammatory action of mildronate in mice using the formalin test, which is validated for the assessment of a two-phase model for tonic pain and localised inflammation (Tjolsen et al., 1992). Although mildronate did not affect the first phase nociception, it reduced the licking behaviour during the second phase, which is attributed to the inflammatory response. The anti-inflammatory action of mildronate was comparable to that of indomethacin, a reference drug of the cyclooxygenase $(\mathrm{COX})$ inhibitor class. At present, we cannot provide a precise mechanism of anti-inflammatory action of mildronate in peripheral tissue, since the late phase followed by formalin injection appeared to depend on a combination of inflammatory reaction caused by different substances, such as glutamate, substance P, and neurokinin (Yaksh, 1997). The present data are in line with those obtained previously: anti-inflammatory action of mildronate in mice cardiac tissue (Klusa et al., 2006; Isajevs et al., 2007) by reducing considerably the expression of NF- $\mathrm{KBp} 65$. This nuclear factor has been linked to inflammation by upregulating various inflammatory cytokines, chemokines and adhesion molecules (Di Stefano et al., 2002). 
In conclusion, our data demonstrate for the first time that mildronate protects peripheral nerve tissue from cell death and inflammatory processes, probably by action focused on the regulation of mitochondrial functions. Our data suggest that mildronate can be useful in the protection of different neuropathies associated with mitochondrial toxicity.

\section{ACKNOWLEDGEMENTS}

This work was supported by the Latvian Council of Science Grant Nr. 05-1418; ESF Grant ESS2004/3; Contract No. 453, between the Latvian Institute of Organic Synthesis and the Joint Stock Company "Grindex"; Contract No. 2377, between the University of Latvia and the Joint Stock Company "Grindex"; and a L'ORÉAL Latvian "For Women In Science" fellowship with the support of the Latvian $\mathrm{Na}$ tional Commission for UNESCO and the Latvian Academy of Sciences.

\section{REFERENCES}

Abbadie, C., Lindia, J.A., Cumiskey, A.M., Peterson, L.B., Mudgett, J.S., Bayne, E.K., DeMartino, J.A., Maclntyre, D.E., Forrest, M.J. (2003). Impaired neuropathic pain responses in mice lacking the chemokine receptor CCR2. Proc. Natl. Acad. Sci. USA, 100(13), 7947-7952.

Badley, A.D., Roumier, T., Lum, J.J., Kroemer, G. (2003). Mitochondrionmediated apoptosis in HIV-1 infection. Trends Pharmacol. Sci., 24(6), 298-305.

Baumann, N., Pham-Dinh, D. (2001). Biology of oligodendrocyte and myelin in the mammalian central nervous system. Physiol. Rev., 81(2), 871-927.

Bellasio, S., Nicolussi, E., Bertorelli, R., Reggiani, A. (2003). Melanocortin receptor agonists and antagonists modulate nociceptive sensitivity in the mouse formalin test. Eur. J. Pharmacol., 482(1-3), 127-132.

Benbrik, E., Chariot, P., Bonavaud, S., Ammi-Said, M., Frisdal, E., Rey, C., Gherardi, R., Barlovatz-Meimon, G. (1997). Cellular and mitochondrial toxicity of zidovudine (AZT), didanosine (ddI) and zalcitabine (ddC) on cultured human muscle cells. J. Neurol. Sci., 149(1), 19-25.

Capone, F., Aloisi, A.M. (2004). Refinement of pain evaluation techniques. The formalin test. Ann. Ist. Super. Sanita., 40(2), 223-229.

Cherry, C.L., Skolasky, R.L., Lal, L., Creighton, J., Hauer, P., Raman, S.P., Moore, R., Carter, K., Thomas, D., Ebenezer, G.J., Wesselingh, S.L., McArthur, J.C. (2006). Antiretroviral use and other risks for HIV-associated neuropathies in an international cohort. Neurology, 66(6), $867-873$.

Collins, M.L., Sondel, N., Cesar, D., Hellerstein, M.K. (2004). Effect of nucleoside reverse transcriptase inhibitors on mitochondrial DNA synthesis in rats and humans. J. Acquir. Immune Defic. Syndr., 37(1), 1132-1139.

Cui, L., Locatelli, L., Xie, M.Y., Sommadossi, J.P. (1997). Effect of nucleoside analogs on neurite regeneration and mitochondrial DNA synthesis in PC-12 cells. J. Pharmacol. Exp. Ther., 280(3), 1228-1234.
Dambrova, M., Liepinsh, E., Kalvinsh, I. (2002). Mildronate: Cardioprotective action through carnitine-lowering effect. Trends Cardiovasc. Med., 12(6), 275-279.

Di Stefano, A., Caramori, G., Oates, T., Capelli, A., Lusuardi, M., Gnemmi, I., Ioli. F., Chung. K.F., Donner, C.F., Barnes, P.J., Adcock. I.M. (2002). Increased expression of nuclear factor- $\kappa \mathrm{B}$ in bronchial biopsies from smokers and patients with COPD. Eur. Respir. J., 20(3), 556-563.

Fujita, R., Kiguchi, N., Ueda, H. (2007) LPA-mediated demyelination in ex vivo culture of dorsal root. Neurchem. Int., 50(2), 351-355.

Isajevs, S., Pupure, J., Gordjušina, V., Kratovska, A., Taivans, I., Vīksna, L., Kalviňš, I., Kluša, V. (2007). Mildronate protects stavudine and lamivudine induced cardiotoxicity. Proc. Latvian Acad. Sci., Section B, 61(1-2), 26-32.

Klusa, V., Pupure, J., Isajevs, S., Rumaks, J., Gordjushina, V., Kratovska, A., Taivans, I., Svirskis, S., Viksna, L., Kalvinsh, I. (2006). Protection of azidothymidine-induced cardiopathology in mice by mildronate, a mitochondria-targeted drug. Bas. Clin. Pharmacol. Toxicol., 99(4), 323-328.

Lewis, W., Kohler, J.J., Hosseini, S.H., Haase, C.P., Copeland, W.C., Bienstock, R.J., Ludaway, T., McNaugh, J., Russ, R., Stuart, T., Santoianni, R. (2006). Antiretroviral nucleosides, deoxynucleotide carrier and mitochondrial DNA: Evidence supporting the DNA pol gamma hypothesis. AIDS, 20(5), 675-684.

Petit, C., Pietri-Rouxel, F., Lesne, A., Leste-Lasserre, T., Mathez, D., Naviaux, R.K., Sonigo, P., Bouillaud, F., Leibowitch, J. (2005). Oxygen consumption by cultured human cells is impaired by a nucleoside analogue cocktail that inhibits mitochondrial DNA synthesis. Mitochondrion, 5(3), 154-161.

Pupure, J., Fernandes, M.A.S., Santos, M.S., Moreno, A.J.M., Kalvinsh, I., Klusa, V., Oliveira, C.R. (2008). Mitochondria as the target for mildronate's protective effects in azidothymidine (AZT)-induced toxicity of isolated rat liver mitochondria. Cell Biochem. Funct., 26(5), 620-631.

Pupure, J., Isajevs, S., Skapare, E., Rumaks, J., Svirskis, S., Kalvinsh, I., Klusa, V. (2010). Neuroprotective properties of mildronate, a mitochondria-targeted small molecule. Neurosci. Lett., 470(2), 100-105.

Purevjav, E., Nelson, D.P., Varela, J.J., Jimenez, S., Kearney, D.L., Sanchez, X.V., DeFreitas, G., Carabello, B., Taylor, M.D., Vatta, M., Shearer, W.T., Towbin, J.A., Bowles, E. (2007). Myocardial Fas ligand expression increases susceptibility to AZT-induced cardiomyopathy. Cardiovasc. Toxicol., 7(4), 255-263.

Scarsella, A., Coodley, G., Shalit, P., Anderson, R., Fisher, R.L., Liao, Q., Ross, L.L., Hernandez, J.E. (2002). Stavudine-associated peripheral neuropathy in zidovudine-nalve patients: Effect of stavudine exposure and antiretroviral experience. Adv. Ther., 19(1), 1-8.

Tjolsen, A., Berge, O.G., Hunskaar, S., Rosland, J.H., Hole, K. (1992). The formalin test: An evaluation of the method. Pain, 51(1), 5-17.

Ueda, H. (2008). Peripheral mechanisms of neuropathic pain — involvement of lysophosphatidic acid receptor-mediated demyelination. Mol. Pain, 4, 11.

Weber, J., Mitchell, D., Kamerman, P.R. (2007) Oral administration of stavudine induces hyperalgesia without affecting activity in rats. Physiol. Behav., 92(5), 807-813.

Yaksh, T.L. (1997) Preclinical models of nociception. In: Anesthesia: Biologic foundations. Yaksh, T.L., Lynch, C. III, Zapol, W.M, et al. (eds.). Philadelphia: Lippincott-Raven, pp. 685-718.

\section{MILDRONĀTA PROTEKTĪVIE EFEKTI PERIFĒRAJĀ NERVU SISTĒMĀ: STAVUDĪNA NEIROPĀTIJAS UN FORMALĪNA IEKAISUMA MODEL,I}

Iepriekšējos pētījumos esam parādījuši mildronāta spēju regulēt mitohondriālos procesus izolētos žurku aknu audos, kā arī normalizēt smadzeṇu audu dažādu signālmolekulu ekspresiju. Šajā darbā pārbaudījām hipotēzi, ka mildronāts spēj uzrādīt protektīvu darbību arī perifērajā nervu sistēmā. To pētījām modeḷvielas — stavudīna izrasītās neiropātijas modelī un formalīna izraisītā iekaisuma procesos. Mildronāts devā $100 \mathrm{mg} / \mathrm{kg}$ būtiski samazināja stavudīna izraisīto deǵeneratīvo šūnu skaitu žurku perifērajos (sēžas nerva) nervu audos, taču neietekmēja samazināto mielīna ekspresiju. Mildronāts līdz kontroles līmenim samazināja iekaisuma reakciju formalīna testa otrajā fāzē, un rezultāts bija salīdzināms ar indometacīna efektu. Šie rezultāti liecina, ka mildronāts spēj regulēt deǵgeneratīvos un iekaisuma procesus perifērajā nervu sistēmā, ko var izskaidrot ar tā spēju regulēt mitohondriālos procesus. Iegūtie dati norāda uz mildronāta iespējamiem protektīvajiem efektiem perifēro neiroloğisko saslimšanu (piemēram, neiropātiju) ārstēšanā. 